\title{
Assessment of Nurse Midwive's Knowledge Concerning Effect of Early Timing of Umbilical Cord Clamping on Maternal and Neonatal outcomes at Delivery Rooms in Maternity Hospitals in Baghdad City.
}

\author{
*Leena Sabah Kamel, , MSc. ${ }^{1}$ Pro. Dr. Rabea Mohsen Ali, $\mathrm{PhD}^{2}$ \\ ${ }^{1}$ (Academic nurse, Burning specialty hospital, Medical city Directorate) \\ ${ }^{2}$ (Professor, Maternal \& Neonate Nursing Department, College of Nursing, University of Baghdad)
}

\begin{abstract}
Background: Delaying umbilical cord clamping allows blood flow between the placenta, the umbilical cord and the baby to continue. The blood which transfers to the baby between birth and cord clamping is called placental transfusion. Placental transfusion may improve circulating volume at birth, which may in turn improve outcome for preterm infants. Early clamping allows for immediate transfer of the infant to the neonatologist.

Objectives: to assess the knowledge of nurse - midwives about early timing of umbilical cord clamping, to identify the effect of early timing of umbilical cord clamping on mother and neonate, to identify the relationship between knowledge and socio-demographic variables.

Methodology: A descriptive analytic design study was carried out in Baghdad Teaching Hospital, Al-Karkh Maternity Hospital, Ibn Al-Balady for Women and Children, Fatima Zahra Hospital for Women and Children, Al-Elwia Maternity Teaching Hospital, and Al-Yarmouk Teaching Hospital, the study starting from 12th November 2015 to 4th August 2016. A purposive sample consisted of (81) nurse-midwives who work in delivery room exclusively, Working in day and night shifts. The questionnaire was consisted of : Part one: General information and socio demographic data, nurse- midwives experience, training courses and time of clamping the umbilical cord, Part two: knowledge of nurse-midwives concerning early cord clamping. Validity of the instrument was established through a panel of (13) experts, and reliability was employed through the computation of alpha correlation coefficient. Data were analyzed by using descriptive, and inferential data analysis.

Result: : the results of study reveal that 71(87.6\%) of nurse-midwives age are less than 50 years old, 76(93.8\%) were midwifery school graduates, 64(79.0\%) were married, 56(69.1\%) had less than ten years of service, and 62(76.6\%) had less than ten years of experiences in the delivery rooms, 67(82.7\%) of Nursemidwives had hospital practicing delivery, 48(59.3\%) of studied sample having training course, 35(72.9\%) had short time (less than week). Time of clamping the umbilical cord", are focused at direct clamping. In the light of early clamping of the umbilical cord shows moderate response. The finding obtain no significant differences at $P>0.05$ between (Knowledge) concerning effect of early timing of umbilical cord clamping and demographical characteristics, as well as general information variables.
\end{abstract}

Keywords: Umbilical cord, early clamping

\section{Introduction}

Umbilical cord clamping is part of the third stage of labor, the time between delivery of the baby and the placenta(1) Cut the umbilical cord represents the beginning of an independent life of newborn, There are umbilical cord clamps which gather the cord clamps with the knife, These clamps are secure and fast, allowing one to first apply the cord clamp and thereafter cut the umbilical cord, next the cord is clamped and cut, the newborn wears a plastic clip on the navel area until the pressed region of the cord has dried and sealed sufficiently, The remaining umbilical stub remains for above to $7-10$ days as it dries and then falls off $(2,3)$ Cut the umbilical cord early, usually completed in the first 30 seconds immediately after birth, regardless of whether the pulse cord was cut, Immediate cord clamping is a practice that has been performed routinely for decades without evidence of benefit, Placental carry of oxygenated blood, nutrients and stem cells continues for several minutes after birth. Physiologic principles proposition that the optimal transition to life outside the womb depends on this transfer. The study authors remind that higher newborn iron levels at birth correlate with less likelihood of childhood anemia, a status with long-term neurologic consequences. Early cut the cord at the outset as part of care known as the "active management of the third stage of the pack", which have been implemented to reduce postpartum hemorrhage, It has now been proven to provide any benefit to the mother and lead to damage to the newborn $(4,5)$. 


\section{Methodology}

A descriptive analytic design study was carried out in Baghdad Teaching Hospital, Al-Karkh Maternity Hospital, Ibn Al-Balady for Women and Children, Fatima Zahra Hospital for Women and Children, Al-Elwia Maternity Teaching Hospital, and Al-Yarmouk Teaching Hospital, the study starting from $12^{\text {th }}$ November 2015 to $4^{\text {th }}$ August 2016. A purposive sample consisted of (81) nurse-midwives who work in delivery room exclusively, Working in day and night shifts. The questionnaire was consisted of : Part one: General information and socio demographic data, nurse- midwives experience, training courses and time of clamping the umbilical cord, Part two: knowledge of nurse-midwives concerning early cord clamping. Validity of the instrument was established through a panel of (13) experts, and reliability was employed through the computation of alpha correlation coefficient. Data were analyzed by using descriptive, and inferential data analysis.

\section{Results}

Table (1): Distribution of the studied sample according to socio-demographic characteristic variable with comparisons significant

\begin{tabular}{|c|c|c|c|c|}
\hline Demographical var. & Groups & No. & $\%$ & C.S. ${ }^{(*)}$ P-value \\
\hline \multirow{4}{*}{$\begin{array}{l}\text { Nurse-Midwives age } \\
\text { (Per yrs.) }\end{array}$} & $20-29$ & 24 & 29.6 & \multirow{4}{*}{$\begin{array}{l}\square^{2}=6.951 \\
P=0.073 \\
\text { NS }\end{array}$} \\
\hline & $30-39$ & 23 & 28.4 & \\
\hline & $40-49$ & 24 & 29.6 & \\
\hline & $\square \mathbf{5 0}$ & 10 & 12.3 & \\
\hline \multirow[t]{2}{*}{ Level of education } & Midwifery school & 76 & 93.8 & \multirow{2}{*}{$\begin{array}{l}\text { Bin. test } \\
P=0.000(H S)\end{array}$} \\
\hline & Nursing Institute & 5 & 6.2 & \\
\hline \multirow[t]{4}{*}{ Marital Status } & Single & 12 & 14.8 & \multirow{4}{*}{$\begin{array}{l}\square^{2}=129.22 \\
P=0.000 \\
\text { HS }\end{array}$} \\
\hline & Married & 64 & 79 & \\
\hline & Divorced & 1 & 1.2 & \\
\hline & Widow & 4 & 4.9 & \\
\hline \multirow{5}{*}{$\begin{array}{l}\text { Years of Services } \\
\text { (Per yrs.) }\end{array}$} & $1-4$ & 38 & 46.9 & \multirow{5}{*}{$\begin{array}{l}\square^{2}=44.741 \\
P=0.000 \\
(\mathrm{HS}\end{array}$} \\
\hline & $5-9$ & 18 & 22.2 & \\
\hline & $10-14$ & 8 & 9.9 & \\
\hline & $15-19$ & 3 & 3.7 & \\
\hline & $\square \mathbf{2 0}$ & 14 & 17.3 & \\
\hline \multirow{5}{*}{$\begin{array}{l}\text { Years of experiences } \\
\text { in the delivery rooms } \\
\text { (Per yrs.) }\end{array}$} & $1-4$ & 51 & 63 & \multirow{5}{*}{$\begin{array}{l}\square^{2}=94.7411 \\
P=0.000 \\
\text { HS }\end{array}$} \\
\hline & $5-9$ & 11 & 13.6 & \\
\hline & $10-14$ & 8 & 9.9 & \\
\hline & $15-19$ & 5 & 6.2 & \\
\hline & $\square \mathbf{2 0}$ & 6 & 7.4 & \\
\hline
\end{tabular}

${ }^{(*)}$ HS: Highly Sig. at $\mathrm{P}<0.01$; S: Sig. at $\mathrm{P}<0.05$; Testing based on One-Sample Chi-Square test, as well as Binomial test.

Table (1) shows relative to "Nurse- Midwives age groups", studied sample are seems to be similarly distributed, and they are accounted 71(87.6\%) for whom age are less than 50 years old. With respect to "Educational Levels", most of studied sample had midwifery school educational level, and they accounted 76(93.8\%), while who had Nursing institute education level are accounted 5(6.2\%). Most of studied sample are married, and they are accounted 64(79.0\%), while leftover of single, widow, and divorced are reported $12(14.8 \%), 4(4.9 \%)$, and $1(1.2 \%)$ respectively.

Regarding to " Years of Service", results illustrated that most of studied sample had less than ten years and accounted 56(69.1\%). In addition to that, "Years of experiences in the delivery rooms", results illustrated that most of studied sample had less than ten years and accounted 62(76.6\%).

Table (2): Distribution of the studied sample according to practicing delivery and training courses variables with comparisons significant

\begin{tabular}{|c|c|c|c|c|}
\hline Demographical var. & Groups & No. & $\%$ & C.S. ${ }^{(*)}$ P-value \\
\hline \multirow[t]{2}{*}{ Practicing delivery } & Hospital & 67 & 82.7 & \multirow{2}{*}{$\begin{array}{l}\text { Bin. test } \\
P=0.000(H S)\end{array}$} \\
\hline & Home and Hospital & 14 & $\mathbf{1 7 . 3}$ & \\
\hline \multirow[t]{2}{*}{ Training Course } & Yes & 48 & 59.3 & \multirow{2}{*}{$\begin{array}{l}\text { Bin. test } \\
P=0.120(N S)\end{array}$} \\
\hline & No & 33 & 40.7 & \\
\hline \multirow[t]{3}{*}{ Duration of training course } & Short time(less than week) & 35 & 72.9 & \multirow{3}{*}{$\begin{array}{l}\square^{2}=34.625 \\
P=0.000 \\
\text { HS }\end{array}$} \\
\hline & Medium time(1-2 weeks) & 9 & 18.8 & \\
\hline & Long time(1-6 months) & 4 & 8.3 & \\
\hline \multirow[t]{6}{*}{ Name of the courses } & Midwifery and obstetric & 42 & 87.5 & \multirow{6}{*}{$\begin{array}{l}\square^{2}=173.50 \\
P=0.000 \\
\text { (HS }\end{array}$} \\
\hline & How neonate born & 1 & 2.1 & \\
\hline & Painless delivery & 1 & 2.1 & \\
\hline & Neonate resuscitation & $\mathbf{1}$ & 2.1 & \\
\hline & Pre- post neonate care & 1 & 2.1 & \\
\hline & Unicef & 2 & 4.2 & \\
\hline
\end{tabular}


Assessment of Nurse Midwive's Knowledge Concerning Effect of Early Timing of Umbilical Cord.

\begin{tabular}{|l|l|l|l|l|}
\hline Time of clamping the & Direct & 25 & 30.9 & ${ }^{2}=21.864$ \\
\cline { 2 - 4 } umbilical cord & 1 - 3 minutes & 35 & 43.2 & P=0.000 \\
\cline { 2 - 4 } & Above 3 minutes & 13 & 16 & \\
\cline { 2 - 4 } & After cord pulse stop & 8 & 9.9 & \\
\hline
\end{tabular}

${ }^{(*)}$ HS: Highly Sig. at $\mathbf{P}<0.01$; S: Sig. at $\mathbf{P}<0.05$; Testing based on One-Sample Chi-Square test, as well as Binomial test.

Table (2) shows with respect to "Practicing Delivery", most studied Nurse-midwives had hospital practicing delivery, and they are accounted 67(82.7\%). On nurse-midwives "Training Course", results illustrated that $48(59.3 \%)$ of studied sample having training course previously, and statistically reported no significant difference at P>0.05 compared with whom hadn't . "Duration of training course", results illustrated that most of applicable studied sample had short time (less than week), and they are accounted 35(72.9\%). Regarding to "Name of the courses", most of studied sample conjunctive to "Midwifery and Obstetric", and accounted 42(87.5\%). Finally, "Time of clamping the umbilical cord", are focused at direct and (1-3) minutes, and they are accounted $25(30.9 \%)$, and 35(43.2\%) respectively.

Table(3): Summary Statistics of Early Clamping of the Umbilical Cord distributed in light of Impact of early timing for mother

\begin{tabular}{|c|c|c|c|c|c|c|c|}
\hline Impact of early timing for mother & Resp. & No. & $\%$ & MS & SD & RS\% & Ass. \\
\hline \multirow[t]{2}{*}{ It reduces the duration of third stage of labor } & Incorrect & 20 & 24.7 & \multirow[t]{2}{*}{1.75} & \multirow[t]{2}{*}{0.43} & \multirow[t]{2}{*}{87.5} & \multirow[t]{2}{*}{$\mathbf{H}$} \\
\hline & Correct & 61 & 75.3 & & & & \\
\hline \multirow{2}{*}{$\begin{array}{l}\text { Increasing the proportion of antibodies in the } \\
\text { blood of mothers with }(\mathrm{Rh}-\mathrm{ve} \& \text { newborn } \mathrm{Rh}+)\end{array}$} & Incorrect & 32 & 39.5 & \multirow[t]{2}{*}{1.60} & \multirow[t]{2}{*}{0.49} & \multirow[t]{2}{*}{80.0} & \multirow[t]{2}{*}{ M } \\
\hline & Correct & 49 & 60.5 & & & & \\
\hline \multirow[t]{2}{*}{ Cause a retention of the placenta. } & Incorrect & 48 & 59.3 & \multirow[t]{2}{*}{1.41} & \multirow[t]{2}{*}{0.49} & \multirow[t]{2}{*}{70.5} & \multirow[t]{2}{*}{ M } \\
\hline & Correct & 33 & 40.7 & & & & \\
\hline \multirow[t]{2}{*}{ It leads to post partum hemorrhage (PPH) } & Incorrect & 55 & 67.9 & \multirow[t]{2}{*}{1.32} & \multirow[t]{2}{*}{0.47} & \multirow[t]{2}{*}{66.0} & \multirow[t]{2}{*}{$\mathbf{L}$} \\
\hline & Correct & 26 & 32.1 & & & & \\
\hline \multirow[t]{2}{*}{ Leads to increased placental weight. } & Incorrect & 55 & 67.9 & \multirow[t]{2}{*}{1.32} & \multirow[t]{2}{*}{0.47} & \multirow[t]{2}{*}{66.0} & \multirow[t]{2}{*}{$\mathbf{L}$} \\
\hline & Correct & 26 & 32.1 & & & & \\
\hline \multirow[t]{2}{*}{ It increases the amount of blood lost. } & Incorrect & 48 & 59.3 & \multirow[t]{2}{*}{1.41} & \multirow[t]{2}{*}{0.49} & \multirow[t]{2}{*}{70.5} & \multirow[t]{2}{*}{ M } \\
\hline & Correct & 33 & 40.7 & & & & \\
\hline \multirow{2}{*}{$\begin{array}{l}\text { It leads to increased volume of blood remaining } \\
\text { in the placenta }\end{array}$} & Incorrect & 39 & 48.1 & \multirow[t]{2}{*}{1.52} & \multirow[t]{2}{*}{0.50} & \multirow[t]{2}{*}{76.0} & \multirow[t]{2}{*}{ M } \\
\hline & Correct & 42 & 51.9 & & & & \\
\hline
\end{tabular}

L:Low; M:Moderate; H:High Red color items are reversed to the scoring scale assessment.

Table (3) shows that all items regarding to early clamping of the umbilical cord distributed in light of impact of early timing for mother are assigned good knowledge for nurses midwives, since a high item's assess accounted 1(14.28\%) item, and a moderate item's assess accounted 4(57.14\%), the leftover low are accounted 2( $28,57 \%$ ).

Table(4): Summary Statistics of Early Clamping of the Umbilical Cord distributed in light of Impact of early timing for Newborn

\begin{tabular}{|c|c|c|c|c|c|c|c|}
\hline Impact of early timing for newborn & Resp. & No. & $\%$ & MS & SD & $\mathbf{R S \%}$ & Ass. \\
\hline \multirow[t]{2}{*}{ It increases the proportion of neonatal resuscitation. } & Incorrect & 22 & 27.2 & \multirow[t]{2}{*}{1.73} & \multirow[t]{2}{*}{0.45} & \multirow[t]{2}{*}{86.5} & \multirow[t]{2}{*}{$\mathbf{H}$} \\
\hline & Correct & 59 & 72.8 & & & & \\
\hline \multirow{2}{*}{$\begin{array}{l}\text { It reduces the chance of newborn additional amount } \\
\text { of blood. }\end{array}$} & Incorrect & 30 & 37 & \multirow[t]{2}{*}{1.63} & \multirow[t]{2}{*}{0.49} & \multirow[t]{2}{*}{81.5} & \multirow[t]{2}{*}{$\mathbf{M}$} \\
\hline & Correct & 51 & 63 & & & & \\
\hline \multirow[t]{2}{*}{ It reduces the proportion of bilirubin in the blood. } & Incorrect & 28 & 34.6 & \multirow[t]{2}{*}{1.65} & \multirow[t]{2}{*}{0.48} & \multirow[t]{2}{*}{82.5} & \multirow[t]{2}{*}{$\mathbf{M}$} \\
\hline & Correct & 53 & 65.4 & & & & \\
\hline \multirow{2}{*}{$\begin{array}{l}\text { It reduces the rate of passage of the antibodies from } \\
\text { mother to baby in the event of a negative factor for } \\
\text { the mother. }\end{array}$} & Incorrect & 25 & 30.9 & \multirow[t]{2}{*}{1.69} & \multirow[t]{2}{*}{0.46} & \multirow[t]{2}{*}{84.5} & \multirow[t]{2}{*}{$\mathbf{H}$} \\
\hline & Correct & 56 & 69.1 & & & & \\
\hline \multirow[t]{2}{*}{ Reduce the burden of the circulatory system. } & Incorrect & 26 & 32.1 & \multirow[t]{2}{*}{1.68} & \multirow[t]{2}{*}{0.47} & \multirow[t]{2}{*}{84.0} & \multirow[t]{2}{*}{$\mathbf{H}$} \\
\hline & Correct & 55 & 67.9 & & & & \\
\hline \multirow[t]{2}{*}{ It is associated with a lack of hemoglobin. } & Incorrect & 29 & 35.8 & \multirow[t]{2}{*}{1.64} & \multirow[t]{2}{*}{0.48} & \multirow[t]{2}{*}{82.0} & \multirow[t]{2}{*}{$\mathbf{M}$} \\
\hline & Correct & 52 & 64.2 & & & & \\
\hline \multirow{2}{*}{$\begin{array}{l}\text { Increase incidence of respiratory distress syndrome } \\
\text { in preterm infants. }\end{array}$} & Incorrect & 32 & 39.5 & \multirow[t]{2}{*}{1.60} & \multirow[t]{2}{*}{0.49} & \multirow[t]{2}{*}{80.0} & \multirow[t]{2}{*}{ M } \\
\hline & Correct & 49 & 60.5 & & & & \\
\hline It reduces the proportion of red blood cells. & Incorrect & 39 & 48.1 & 1.52 & 0.50 & 76.0 & $\mathbf{M}$ \\
\hline & Correct & 42 & 51.9 & & & & \\
\hline Carbon dioxide in the blood increased and this & Incorrect & 27 & 33.3 & 1.67 & 0.47 & 83.5 & $\mathbf{H}$ \\
\hline increases acidity and suffocation. & Correct & 54 & 66.7 & & & & \\
\hline It increases the proportion of short-term and long- & Incorrect & 27 & 33.3 & 1.67 & 0.47 & 83.5 & $\mathbf{H}$ \\
\hline term health problems. & Correct & 54 & 66.7 & & & & \\
\hline
\end{tabular}

${ }^{(*)}$ L:Low; M:Moderate; H:High 
Table (4) shows that all of study items regarding to this part are assigned good knowledge for nurses midwives knowledge concerning impact of early timing of umbilical cord clamping on neonatal outcomes at delivery rooms in maternity hospitals, since a high item's assess accounted 5(50\%) items, and leftover moderate item's assess also accounted 5(50\%).

Table (5) : Summary statistics for an overall assessments of knowledge and practices concerning nurses midwives staff

\begin{tabular}{|c|c|c|c|c|c|c|}
\hline Domain & Sub and Main Domains & No. & MS & DS & $\mathbf{R S \%}$ & Ass. \\
\hline \multirow{3}{*}{ 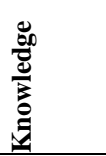 } & Impact of early timing for mother & 81 & 1.626 & 0.275 & 81.3 & $\mathbf{M}$ \\
\hline & Impact of early timing for newborn & 81 & 1.648 & 0.262 & 82.4 & M \\
\hline & Early clamping of the umbilical cord & 81 & 1.637 & 0.169 & 81.9 & $\mathbf{M}$ \\
\hline
\end{tabular}

a. Early clamping of the umbilical cord: In light of (Impact of early timing for mother), shows that studied sub main domain had a moderate /high response, and regarding to actual relative sufficiency value of an overall assessment, this domain had reported high moderate response, and it could be conclude that this part are assigned good knowledge for nurses midwives staff in view of early clamping of the umbilical cord on maternal outcomes.

b. Early clamping of the umbilical cord: In light of (Impact of early timing for newborn), shows that studied sub main domain had a moderate/ high response, and regarding to actual relative sufficiency value of an overall assessment, this domain had reported high moderate response, and it could be conclude that this part are assigned good knowledge for nurses midwives staff in view of early clamping of the umbilical cord on neonatal outcomes.

c. Early clamping of the umbilical cord: shows that studied main domain had a moderate response, and regarding to actual relative sufficiency value of an overall assessment, this main domain had reported high moderate/ high response, and it could be conclude that this part are assigned good knowledge for nurses midwives staff concerning early clamping of the umbilical cord on maternal and neonatal outcomes at delivery rooms in maternity hospitals.

Table (5): Relationship between an overall assessment (Knowledge) concerning effect of timing of umbilical cord clamping regarding to some demographical characteristics

\begin{tabular}{|l|l|l|l|}
\hline Demographical Characteristics \& & \multicolumn{3}{l|}{ Early clamping of the umbilical cord } \\
\cline { 2 - 4 } General Information Variables & C.C. & Sig. & C.S. \\
\hline Midwife's age & $\mathbf{0 . 1 8 8}$ & $\mathbf{0 . 3 9 9}$ & NS \\
\hline Level of education & $\mathbf{0 . 1 2 6}$ & $\mathbf{0 . 2 5 2}$ & NS \\
\hline Marital Status & $\mathbf{0 . 1 3 4}$ & $\mathbf{0 . 6 8 6}$ & NS \\
\hline Years of Services & $\mathbf{0 . 1 1 3}$ & $\mathbf{0 . 9 0 2}$ & NS \\
\hline Years of Experiences in the Delivery Room & $\mathbf{0 . 2 3 6}$ & $\mathbf{0 . 3 1 3}$ & NS \\
\hline Practicing delivery & $\mathbf{0 . 0 1 9}$ & $\mathbf{0 . 8 6 3}$ & NS \\
\hline Training Course & $\mathbf{0 . 0 3 3}$ & $\mathbf{0 . 7 6 8}$ & NS \\
\hline Duration of training course & $\mathbf{0 . 1 9 6}$ & $\mathbf{0 . 3 8 3}$ & NS \\
\hline
\end{tabular}

Results shows that regarding to contingency coefficients and testing significant, weak relationships are accounted with no significant at $\mathrm{P}>0.05$ between (Knowledge) concerning effect of timing of umbilical cord clamping and demographical characteristics, as well as general information variables.

\section{Discussion}

Analysis of the nurse-midwives demographic characteristics indicated that the higher percentage 71(87.6\%) for whom age are less than 50 years old, that s' disagree with Emon, (2015) which stated that the older midwives had significant higher perception than the younger midwives ${ }^{(6)}$. Regarding "Educational Levels", most of studied sample had midwifery school educational level, and they accounted 76(93.8\%), while who had Nursing institute education level are accounted 5(6.2\%). Styles et al.; (2008) stated that the education of a skilled birth attendant should be of good quality at both pre service and in-service levels with a system for supportive supervision ${ }^{(7)}$. Regarding years of services had less than ten years and accounted 56(69.1\%). AlAmmari.; (2008) in Baghdad reported that (28\%) of nurse midwives were employed for (1-10) years, while ( $32 \%$ ) of them spent between (1-5) years of experience in midwifery ${ }^{(8)}$. Regarding practicing delivery, the highest percentage 67(82.7\%) work in hospital, that's disagree with Rajesh and Yogesh, (2015), which stated that $(53.96 \%)$ nurse-midwives practicing delivery at home and $(25.39 \%)$ at hospital ${ }^{(9)}$. Regarding training course in midwifery, the highest percentage 48(59.3\%) participated in training course for less than week this result are in agreement with study of Al-Ammari (2008), who reported that 48 (59.3\%) of nurse midwives sample having training course ${ }^{(8)}$. This result is consistent with study conducted by Bij De Vaate et al; (2002) 
which concluded that the initial training of the midwives involved a six week course from a national curriculum on the management of uncomplicated labor and the prevention, detection and response to obstetric complications ${ }^{(10)}$. Regarding the timing of umbilical cord clamping, the highest percentage $35(43.2 \%)$ from nurse midwives ensured (1-3mints). This was in agreement with WHO guidelines recommend cord clamping between one to three minutes after the birth ${ }^{(11)}$.

Study results shows that all items regarding to early clamping of the umbilical cord distributed in light of impact of early timing for mother are assigned good knowledge for nurses midwives, since a high item's assess accounted 1(14.28\%) item, and a moderate item's assess accounted 4(57.14\%), the leftover low are accounted $2(28,57 \%)$. Ola et al.; (2013) reported that early cord clamping, did not have a significant effect on maternal outcomes ${ }^{(12)}$. Susan; et al (2014) showed in their study that no significant differences seen between early and late cord clamping groups for the primary maternal outcome of severe postpartum hemorrhage or for the secondary outcomes of postpartum hemorrhage of $500 \mathrm{ml}$ or more or mean blood loss, which agree with the present study ${ }^{(2)}$. Studies have shown that early cord clamping reduces the duration of third stage of labor ${ }^{(13)}$. That's in agreement with result of this study that (14.28\%) from nurse-midwives were ensured that the early cord clamping lead to reduces the duration of third stage of labor.

Results shows that all of study items regarding to impact early timing of umbilical cord clamping on neonatal outcomes assigned good knowledge for nurses midwives, since a high item's assess accounted 5(50\%) items, and leftover moderate item's assess also accounted 5(50\%.).Early cord cutting is associated with a double chance of anemia at 3 to 6 months in term infants, and that evidence has shown up to a 60 percent reduction in risk for infant anemia for each minute that cord cutting is delayed when maternal anemia is existing (14, 15).

Results shows that regarding to contingency coefficients and testing significant, weak relationships are accounted with no significant at $\mathrm{P}>0.05$ between (Knowledge) concerning effect of timing of umbilical cord clamping and demographical characteristics, as well as general information variables. Accordance with the preceding results, it could be conclude that the studied questionnaire of studying (Knowledge) concerning effect of timing of umbilical cord clamping on maternal and neonatal outcomes at delivery rooms in maternity hospitals could be generalize on the studied population even though differences with studied subjects in light of their demographical characteristics, and general information variables. Present study revealed that there were no significant between the nurses knowledge and their educational level.That's disagree with Ahrar \& Rabea'a (2010) that there was a high significant association between nurse-midwives' practices regarding 2 nd stage of labor including cord clamping and their educational level ${ }^{(16)}$. The adoption of knowledge was influenced by the desire of the midwife to apply the research-based knowledge in the practice, The midwives who read had adopted more knowledge than the others ${ }^{(\mathbf{1 7})}$, Also, it was found that the birth attendance in all educational levels needs educational and training courses for providing high quality of care at delivery units to prevent maternal and fetal mortality rate ${ }^{(\mathbf{1 8})}$. Present finding revealed that there were no significant between the nurses knowledge and training course, It was found that in-service training is essential to ascertain that midwives' skills and their understanding quality of care have been updated to maintain high quality in their nursing and midwifery practices and give them the opportunity for high quality of performance ${ }^{(2)}$.

\section{Conclusions}

The study concluded that time of clamping the umbilical cord are focused at the 1-3 min. They have moderate knowledge concerning impact of early timing of umbilical cord clamping on mother and neonate outcomes. The study also showed weak relationship between (knowledge)concerning effect of timing of umbilical cord clamping (UCC) and demographical characteristics as well as general information variable

\section{Recommendation}

Spreading health awareness between nurse-midwives through seminars and the media, and training courses about importance of timing of UCC for mother and newborn.

\section{References}

[1]. Rabe H, Jewison A, Alvarez RF, et al;: Milking compared with delayed cord clamping to increase placental transfusion in preterm neonates: a randomized controlled trial. Obstet Gynecol, Vol.117, NO.2, Pt.1, 2011, pp:205-211

[2]. Susan J, Philippa M, Therese D, et al;: Effect of timing of umbilical cord clamping of term infants on maternal and neonatal outcomes, Evidence-Based Child Health: A Cochrane Review Journal , Vol. 9, Issue 2, 2014, pp: 303-397.

[3]. Amir K, Liron B, Arieh R, et al ;: Immediate versus Delayed Umbilical Cord Clamping in Premature Neonates Born < 35 Weeks, american journal of perinatology, vol.24, NO.5, 2007,PP: 307-315.

[4]. McDonald S and Middleton P.: Effect of timing of umbilical cord clamping of term infants on maternal and neonatal outcomes, Cochrane Database of systematic Reviews Vol.16, Issue 2, 2008.

[5]. Uwins C and Hutchon D.: Delayed umbilical cord clamping after childbirth: potential benefits to baby's health, Browse Journals Pediatric Health, Medicine and Therapeutics Vol. 5,2014, pp: 161-171

[6]. Emon U, Alberta D, Mary M, et al;: Influence of Age on Perception of Midwives and Their Performance in Objective Structured Clincial Examination (Osce) in Nigeria, Journal of Education and Training Studies, Vol 3, No. 5, 2015,pp:1-4 
[7]. Styles M, Cheyne H and Cheyne R.: “Midwives’ Intrapartum Decision Making” MPhil Thesis, University of Stirling,2008, pp104107.

[8]. Al-Ammari A.: Assessment of Nurse-Midwives Knowledge and Practice Concerning Perinatal Care throughout stages of labor , MSC Thesis, College of Nursing/ University of Baghdad, 2008,pp:64-102.

[9]. Rajesh R and Yogesh K.: Delivery practices in a rural area of North Karnataka - A cross sectional study, International Journal of Advances in Pharmaceutics, Vol.4, Issue 1, 2015, p:2

[10]. Bij de vaate A, Coleman R, Manneh H, et al ;: Knowledge Attitude and Practices of Trained Traditional birth attendant in the Gambia in the prevention, recognition, and Management of postpartum Hemorrhage, Midwifery journal, vol.18, 2002 , pp:3-11.

[11]. WHO.: WHO Recommendations for the Prevention and Treatment of Postpartum Haemorrhage, Evidence Base, WHO: Geneva, 2012 .

[12]. Ola A, Lena H, Jesper C et al ;: Effects of delayed compared with early umbilical cord clamping on maternal postpartum hemorrhage and cord blood gas sampling: a randomized trial, Acta Obstetricia et Gynecologica Scandinavica, Vol. 92, Issue 5, 2013,pp: 567-574.

[13]. Walsh S.: Maternal Effects of Early and Late Clamping of the Umbilical Cord, lancet ,V. $11,1968$.

[14]. McDonald S, Middleton P, Dowswell T, et al;: Effect of timing of umbilical cord clamping of term infants on mother and baby outcomes, Cochrane Database Systematic Review,Vol.16, issue.2, 2013.

[15]. Blouin B, Penny M, Casapia M et al;: Effect of a two-component intervention to change hospital practice from early to delayed umbilical cord clamping in the peruvian amazon, Revista Panamericana De Salud Pública, vol.29, NO. 5, 2011 , pp: $322-328$.

[16]. Ahrar M and Rabea'a M.: Assessment of Nurse-Midwives' Knowledge and Practices toward Second Stage of Labor, Iraqi Sci. J. Nursing, Vol. 23, Special Issue, 2010, p:23.

[17]. Kalliomaki- T.: Midwives as Users of Research-Based Knowledge in Childbirth Nursing, Sairaahoitaja, ,vol. 75,issue. 4, 2002, pp: $7-14$.

[18]. Anonymous.: Antenatal, Delivery, and Newborn Care Received in Jamica, University of North Carolina, Carolina Population Center, Maternal and Neonatal Program Effort Index (MNPI), 1999, P.4. 